\title{
PENGGUNAAN BATU CERMAT DALAM MENGEMBANGKAN KEMAMPUAN BERPIKIR KREATIF DAN BUDAYA LITERASI SISWA
}

\author{
Abdul Hakim \\ SMPN 1 Dolopo Madiun \\ dhakim dolopo@yahoo.co.id
}

\begin{abstract}
:
Based on the data and experience of researchers in classes that are able to show interest in literacy and critical thinking skills is still low. Therefore, researchers applied the Batu Cermat method. Batu Cermat comes from "baca-tulis-uji-cerpen-matematika," (read-write-test-short story mathematics). Batu Cermat aims to civilize literacy and instill communication skills, collaborate, think critically and creatively with students. This article is in the form of qualitative research, the best practice of researchers applying Batu Cermat to students of SMPN 1 Dolopo starting the $2015 / 216$ school year to $2017 / 2018$. The information needed is obtained by the documentation study technique, in the form of using a list of values supported by a questionnaire. Through Batu Cermat, students are given the opportunity to think creatively by making short stories in mathematics. How, with m ema be incorporated math problems or related information in a short story, and be able to solve the problem themselves. The validity is tested its validity with each other carefully and resolved. As a result, students are able to make short, good mathematical nuances of short story work according to the rules of short story writing. Proven Batu Cermat can be a catalyst in civilizing literacy and developing the ability to think creatively students. The Batu Cermat is more optimal, if the reading movement becomes more entrenched and requires patience and cooperation across subjects. Up to now, the students' careful work has published four ISBN short story mathematics books.
\end{abstract}

Keywords: Creative thinking, Literacy Culture, Batu Cermat.

\section{PENDAHULUAN}

Anggapan belajar matematika itu sulit, sepertinya sudah mendarah daging pada banyak orang. Berbagai pendekatan, metode, teknik atau media dikembangkan, agar matematika menjadi lebih mudah, setidaknya menarik bagi siswa. Kesulitan siswa belajar matematika bukan hanya terletak pada masalah perhitungan semata. Banyak ditemukan, yang menjadi persoalan bagi siswa belajar matematika yaitu, bagaimana memahami masalah dan strategi apa yang dipakai untuk memecahkannya. Agar siswa paham dan menguasai, tentunya siswa harus mempunyai bekal cukup serta rajin membaca. Sayangnya, saat ini untuk urusan membaca berada di level bawah. Berdasar survey internasional tentang budaya literasi yang diunggah oleh Gewati (2016) di media online, dari 61 negara, Indonesia peringkat dua dari bawah. Mudah dijumpai di lingkungan kita, sedikit sekali anak-anak usia sekolah memanfaatkan waktu untuk membaca. Hal ini cukup memprihatinkan. Karena berdasar pengalaman penulis, rendahnya budaya membaca ini sangat berpengaruh terhadap prestasi belajar siswa.

Matematika itu unik dan menarik. Banyak digunakan, namun faktanya anak sering mengalami kesulitan. Karenanya penyaji (guru) dan penyajian memegang

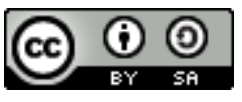

Content from this work may be used under the terms of the Creative Commons AttributionShareAlike 4.0 International License that allows others to share the work with an acknowledgment of the work's authorship and initial publication in this journal. 
peranan. Matematika lebih mudah dipahami jika dilatih intensif dan disajikan menarik. Agar siswa mampu menguasai, menerapkan matematika dalam berbagai bidang serta mengembangkan nalar untuk memecahkan masalah secara mandiri dan bekerja keras. Para guru matematika pasti sering menjumpai, tatkala mengoreksi pekerjaan anak dalam memecahkan masalah matematika yang terkait dengan kehidupan sehari-hari. Jangankan menemukan jawaban, mengidentifikasi saja banyak yang kurang. Anak-anak berkilah, bahwa soal ceritanya sulit dipahami.

Berkaca hal inilah penulis bisa memetik hikmah, agar anak-anak lebih terampil dalam memecahkan masalah matematika. Penulis pun mencoba membuat metode dan teknik baru agar siswa meningkat kreativitas berrpikirnya. Metode dan teknik ini penulis namakan "batu cermat". "Batu" akronim dari "'baca-tulisuji", sedangkan "cermat" singkatan dari "cerita pendek matematika." Pemilhan Batu Cermat ini memperhatikan kondisi terkini dan tantangan abad 21. Di mana generasi sekarang harus disiapkan, salah satunya kompetensi matematika. Penampakan matematika yang boleh dikatakan menyeramkan, membutuhkan pendekatan dan kiat khusus. Memerlukan energi ekstra dan rangsangan tertentu agar matematika dapat memancing kreatifitas belajar berpikir anak. Hal ini menjadi mutlak, karena matematika merupakan ilmu yang bersifat deduktif aksiomatik yang membutuhkan daya nalar tingkat tinggi untuk menguasainya. Anak SMP sebagai remaja, lebih suka sesuatu yang dinamis dan kreatif. Seperti harapan pendidikan abad 21 yang tercantum dalam modul pelatihan bagi instruktur kurikulum 2013, buku Panduan Inspirasi Pembelajaran dan Penilaian Mata Pelajaran Matematika (Kemdikbud, 2017).

Sementara kritis dan kreatifitas tidak datang begitu saja, tanpa ada penyebab yang menumbuhkannya. Keduanya muncul karena ada tantangan, dan kemauan. Cara berpikir dan kemauan untuk meraih sesuatu yang baru atau berbeda merupakan titik fokus kreatifitas (Rowe, 2005). Pemikiran Rowe (2005) ini mengutamakan kemampuan otak dan kepekaan hati. Otak yang bekerja dengan baik akan menghasilkan jika hati menggerakkan. Sebaliknya hati yang tergerak untuk berbuat akan mati gaya, jika tidak ada kemampuan berpikir yang menuntunnya. Hati dan otak yang berpadu akan menghasilkan pemikiran kreatif.

Kreatif juga bisa berarti keterbukaan menyatakan berbagai ide gagasan. Tidak kaku, tertutup hanya mempunyai solusi tunggal. Seperti Putra (2012) menyatakan bahwa berpikir kreatif merupakan proses berpikir. Ada berbagai kemungkinan ide gagasan yang dihasilkan. Tidak itu saja, cara penyelesaiannyapun bisa luas dengan ragam berbeda-deda. Penekannya, bahwa hasil pemikiran itu bisa berbeda-beda, laiknya soal open ended.

Berpikir kreatif juga bisa juga dipandang sebagai aktivitas mental (Moma, 2013). Sebagai sebuah aktivitas mental, perwujudannya dapat diamati dari kepekaan seseorang terhadap masalah. Keberadaan masalah tentunya menuntut seseorang untuk mencari alternatif pemecahan dengan berbagai gagasan baru yang brillian, terbuka dan variatif. Kreatifitas seseorang juga akan tampak dari aktivitas seseorang tersebut mengaitkan antara informasi dan ide untuk menghasilkan solusinya. Peneliti menafsirkan, bahwa berpikir kreatif versi La Moma lebih komplek runutan prosesnya yang melibatkan lebih banyak aspek. 
Aktivitas mental yang menunjukkan kebaruan gagasan dalam memecahkan permasalah juga diungkapkan oleh Siswono (2018). Lebih lanjut ditekankan, bahwa sebuah kreatifitas juga dilihat dari sisi keluwesan dan kefasihan seseorang menyelesaikan permasalahan dengan apik dan tepat sesuai yang diharapkan. Pendapat dosen Unesa ini tampaknya mengarahkan sebuah penyelesaian masalah secara terstruktur dengan ide yang berbeda dari biasanya, berdaya dan berhasil guna. Dalam artikel lain yang diunggah oleh Panjaitan \& Surya (2018) mengemukakan, bahwa berpikir kreatif merupakan kemampuan menciptakan sesuatu yang baru. Karya cipta tersebut bisa berupa gagasan maupun karya nyata. Sedang makna baru ditafsirkan karya yang benar-benar baru, atau mengkombinasi ataupun memodifikasi dari yang sudah ada sehingga bisa jadi menghasilkan sesuatu yang relatif berbeda dengan yang ada sebelumnya.

Tentu saja, dalam proses berpikir kreatif ini bisa diamati dari ciri-cirinya. Diantaranya dari kelancaran, fleksibelitas, keorisinilan, serta keterperincian mengembangkan gagasan berpikir seseorang, seperti dijabarkan Azhari (Panjaitan \& Surya, 2018). Panjaitan \& Surya (2018) ini tampaknya lebih memberikan kebebasan berpikir kepada seseorang untuk mengeksploitasi kemampuannya dengan memanfaatkan sumber daya yang ada. Baik dari dalam dirinya sendiri atau dari luar.

Keluwesan berpikir dalam memodifikasi informasi yang ada untuk menghasilkan karya ini, membuat peneliti cenderung sependapat dengan Agustina dan Edy Surya. Karena dengan kemerdekaan berpikir anak atau siswa cenderung lebih suka mengerjakan sesuatu yang mempunyai berbagai kemungkinan, tanpa kuatir melakukan kesalahan berkarya sesuai dengan bakat, kemampuan dan modal pengetahuan yang dimiliki. Dalam hal ini, ketrampilan berpikir kreatif ini timbul karena siswa mendapat tantangan untuk membuat cerita pendek bernuansa matematika. Anak membuat rancangan ide cerita, memasukkkan masalah matematika dan mengemasnya dalam sebuah alur cerita yang apik yang harus bisa dipecahkan sendiri.

Hasil olah kreatif berikir tersebut akan mudah hilang bila tidak dibudayakan dan terdokumentasi. Di tengah rendahnya berliterasi, ide membuat cermat ini setidaknya menjadi awal gerakan di sekolah sebagai cikal bakal tumbuhnya budaya literasi. Cita-cita besar, yang harus diawali dari kecil, sederhana dan nyata dilaksanakan. Apalagi, jika budaya literasi sudah menjadi kebiasaan berpikir, yang diikuti proses membaca, menulis serta menciptakan karya (Haryanti, 2014). Meski, sebagai sebuah budaya, gerakan literasi sulit berkembang jika berjalan sendiri. Perlu komunitas, bukan asal membaca dan menulis (Jusran, 2017).

Dengan demikian, budaya literasi menjadi suatu aktivitas dengan memberdayakan segala sumber daya manusia dalam bentuk olah karya, olah rasa dan olah pikir yang menghasilkan sesuatu dalam suatu komunitas. Bisa dilatihkan dan dilakukan pembiasaan, terutama kepada generasi milenial. Generasi ala Dylan yang maunya serba instan, menganggap berliterasi itu berat, walau belum berbuat. Oleh karenanya penulis mencoba menerapkan kepada siswa dengan membelajarkan menulis sebuah cerita pendek, yang diimplementasikan di dalam mata pelajaran matematika. 
Memasukkan sastra berupa cerita pendek ke dalam matematika adalah tantangan, dan sepertinya menarik. Kedengarannya aneh, ada cerpen rasa matematika. Tetapi di dunia ini tidak ada yang tidak mungkin. Cerpen adalah bentuk prosa naratif fiktif (Wikipedia, 2017). Ceritanya padat dan langsung ke tujuannya dengan penokohan,alur, plot, tema, bahasa dan ceritanya terfokus. Siswa SMP yang sejak sekolah dasar belajar bahasa Indonesia, secara teori tidak terlalu mengalami kesulitan. Siswa bisa mengungkapkan ide kreatifnya berdasarkan pengalaman empiris yang dilakoninya dalam kehidupan sehari-hari. Ataupun menggunakan daya kontemplatifnya. Yaitu, kemampuan menggunakan daya imajinasi untuk menciptakan sesuatu yang indah berdasar perenungan seseorang (Achmad, 2016). Dengan demikian membuat cerpen tidak harus menggunakan bahasa sastra tingkat tinggi. Bahasa yang muncul dari pribadi sesorang justru dapat menjadi daya tarik dan ciri khas seseorang. Hal ini sudah penulis buktikan, ketika tahun 2016 menerbitkan kumpulan cerpen bertajuk Jangan Korupsi, Ayah!, di dalamnya penulis memasukkan cerita pendek dengan menggunakan permasalahan matematika. Di dalam pembuatan cerpen matematika (cermat), siswa juga diberi rambu-rambu, seperti halnya membuat cerpen pada umumnya (Hakim, 2016).

Pengaplikasikan "cermat" dilakukan dengan metode Batu, baca-tulis-uji. Pelaksanaan pembelajaran dengan metode Batu, dimulai dengan pembiasaan siswa membaca permasalahan atau membaca buku, apapun isinya. Diutamakan berupa bahan bacaan fiksi, soal-soal cerita matematika serta berbagai konsep, contoh pemecahan masalah matematika. Setelah itu peserta didik dilatih untuk menuliskan sebuah cerita pendek bernuansa matematika. Permasalahan matematika terintegrasi langsung dalam alur cerita, bukan sekadar memindah soal dalam bahan bacaan. Jika sudah menjadi cermat, siswa dilatih kembali menguraikan permasalahan serta memecahkannya. Jadi, batu cermat merupakan perpaduan model dan teknik untuk melatih peserta didik meningkatkan ataupun mengembangkan kemampuan berpikir kreatifnya.

Pelaksanaannya Batu berupa aktivitas kegiatan pembelajaran membuat dan mengevaluasi cerpen matematika dengan tiga langkah utama yang dimaksud. Membaca, bermakna siswa membaca materi, contoh-contoh atau soal-soal matematika ataupun materi lain yang mendukung penyusunan cermat. Tulis, bermakna siswa membuat cermat, dan uji siswa bersama teman atau guru mengecek kesahihan cermat.

Pembelajaran di kelas, pembuatan cermat dibuat dalam dua bentuk. Bentuk pertama untuk permulaan. Siswa hanya membuat satu cermat dalam satu bab. Pembuatannyapun bisa dilakukan secara mandiri atau berkelompok, baik berpasangan atau beberapa anak. Jika dirasa sudah menguasai, dilanjutkan tahap kedua, berupa cerpen multi kompetensi dasar.

Cermat yang disusun digunakan sebagai bentuk penilaian ketrampilan. Ada dua hal bisa dinilai, yaitu projek atau praktek. Dalam praktek ada kinerja dan produk. Dengan demikian, cermat adalah salah satu bentuk diversifikasi penilaian dalam kurikulum 2013. Karena dengan membuat cermat multi bab, sekali merengkuh dayung, dua atau tiga pulau terlampaui. Satu bentuk cerpen multi bab 
yang terdiri dari semua kompetensi dasar dalam kurun waktu satu semester, bisa untuk penilaian beberapa kompetensi dasar. Tugas guru dan siswa semakin ringan, dan tujuan pembelajaran tercapai.

Penguasaan anak yang baik dalam batu cermat, diharapkan membangun pondasi dasar kreativitasnya. Hubungan antara Batu Cermat dengan kemampuan berpikir kreatif seperti tertera dalam bagan di bawah ini.

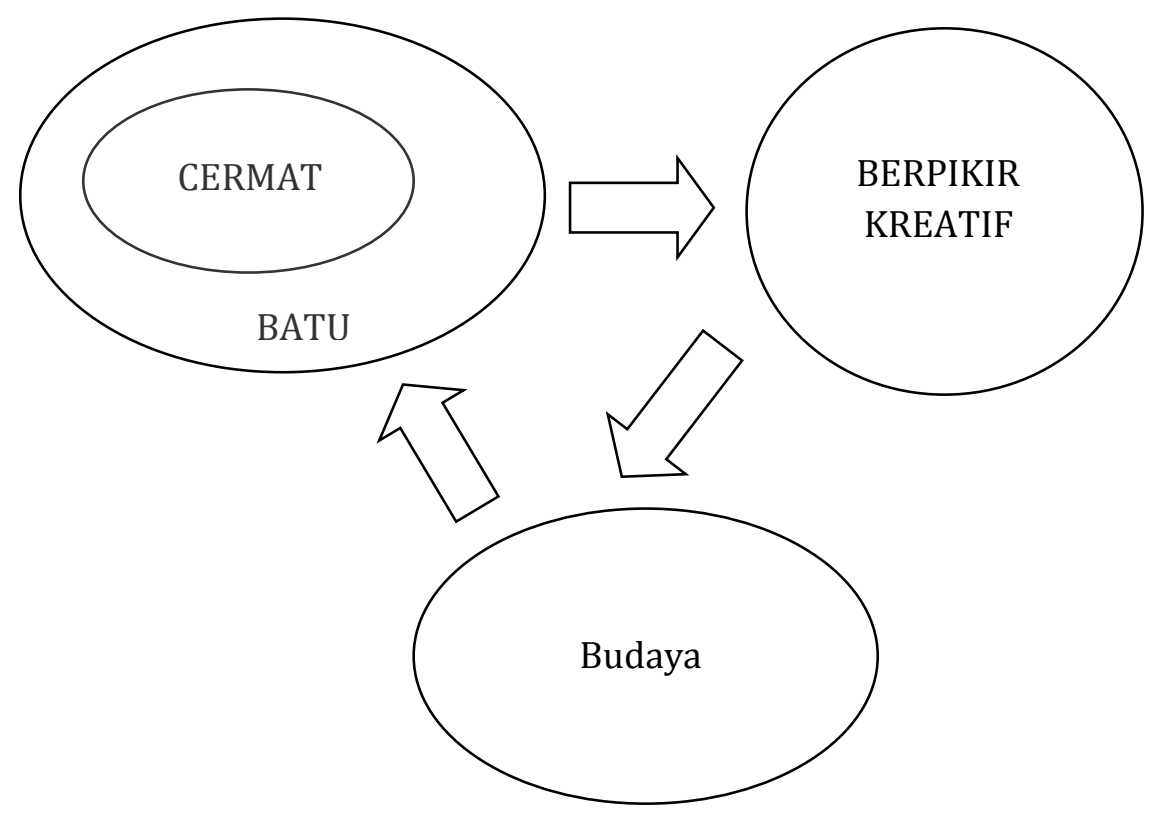

Gambar 1. Bagan hubungan Batu Cermat dengan berpikir kreatif

Karena karya tulis yang disusun ini berkaitan dengan cerpen, penulis menggunakan temuan Rhosalia, Laksono, \& Sukartiningsih (2016) yang melakukan penelitian berkaitan berpikir kreatif. Salah satu temuannya menyatakan bahwa, titik lemah berpikir kreatif anak terletak dari keaslian karya. Untuk itulah, peneliti meletakkan keaslian sebagai salah satu indikator ketercapaian berpikir kreatif anak. Salah satunya dengan perangkat pencari di dunia maya.

\section{METODE PENELITIAN}

Artikel ini berdasar dari penelitian kualitatif, berbentuk best practice, berupa pengalaman penulis menerapkan Batu Cermat di kelas-kelas yang diampu peneliti mulai tahun pelajaran 2015/2016 samppai dengan tahun pelajaran 2017/2018 di SMPN 1 Dolopo Kabupaten Madiun. Kelas-kelasnya merupakan kelas heterogen dengan daya dukung pembelajaran cukup baik. Pada tiga tahun penelitian ini, peneliti mengajar di lima kelas pada tiga tingkat berbeda, kelas VII, VIII dan IX.

Pada tahun pelajaran 2015/2016, peneliti mengajar 5 kelas. Tiga puluh dua anak kelas VII D yang terdiri 12 siswa laki-laki dan 20 siswa perempuan, kelas VII E 32 anak, terdiri 12 siswa laki-laki dan 20 siswa perempuan, kelas VIII C 31 anak terdiri 5 siswa laki-laki dan 26 siswa perempuan, kelas IX C 32 anak yang 


\section{Abdul Hakim}

terdiri 12 siswa laki-laki dan 20 siswa perempuan, serta kelas IX D 30 anak yang terdiri 11 siswa laki-laki dan 19 siswa perempuan.

Tahun pelajaran 2016/2017, peneliti juga mengajar 5 kelas. Kelas VII F 32 siswa yang terdiri 13 siswa laki-laki dan 19 siswa perempuan, kelas VIII H 32 anak, yang terdiri 14 siswa laki-laki dan 18 siswa perempuan, kelas VIII I 32 anak, yang terdiri 13 siswa laki-laki dan 19 siswa perempuan, kelas VIII J 32 anak yang terdiri 13 siswa laki-laki dan 19 siswa perempuan, serta kelas IX C 31 anak yang terdiri 5 siswa laki-laki dan 26 siswa perempuan.

Sedang untuk tahun pelajaran 2017/2018, peneliti mengajar di kelas IX I terdiri dari 32 anak, 10 laki-laki dan 22 perempuan. Kelas IX J, 32 anak terdiri dari 12 laki-laki dan 20 perempuan, kelas VIII D 32 anak, terdiri dari 13 laki-laki 19 perempuan, Kelas VIII E 32 anak, terdiri dari 13 laki-laki dan19 perempuan, dan kelas VII H 32 anak terdiri dari 16 laki-laki serta 16 perempauan.

Teknik yang dilakukan berupa teknik studi dokumentasi, berupa penggunaan daftar nilai peneliti yang dilakukan pada kelas-kelas yang peneliti ampu pada periode penelitian, berdasar rubrik penelilian yang telah ditetapkan.

Data yang diperoleh diolah berdasarkan capaian siswa dibandingkan terhadap KKM (Kriteria Ketuntasan Minimal) mata pelajaran matematika di SMPN 1 Dolopo, yaitu 70. Predikat capaian sebagai acuan menentukan tingkat perkembangan berpikir kreatif dibuat peneliti berpedoman cara menentukan predikat sesuai dengan buku Panduan Penilaian oleh Pendidik dan Satuan Pendidikan yang dikeluarkan oleh Kementerian Pendidikan dan Kebudayaan (Direktorat Pembinaan SMP, 2017), dengan ketentuan sebagai berikut.

Tabel 1. Predikat tingkat berpikir kreatif siswa

\begin{tabular}{cc}
\hline Rentang Nilai & Tingkat Berpikir Kreatif \\
\hline $91-100$ & Sangat kreatif \\
$81-90$ & Kreatif \\
$70-80$ & Cukup kreatif \\
$<70$ & Kurang kreatif \\
\hline
\end{tabular}

Berpedoman kriteria tersebut, indikator ketercapaian pengembangan berpikir kreatif terpenuhi jika lebih dari atau sama dengan $50 \%$ peserta didik yang peneliti ampu, capaian membuat cermat mendapatkan nilai lebih dari atau sama dengan 81, berpredikat sangat kreatif dan kreatif. Sedangkan budaya literasi siswa didasarkan dari kuantitas, dan proses saat siswa berkonsultasi di rentang waktu penyusunan pembuatan cermat. Bagaimana siswa mau menulis, mencari bahan literasi, mengembangkan ide, memperbaiki hingga terwujudnya cermat. Sebagai pendukung data dokumentatif, peneliti membuat angket. Angket pada penelitian baru terlaksana pada tahun ketiga. Hal ini terjadi, karena memang pada awalnya, 
penerapan batu cermat ini sebagai bentuk inovasi peneliti dalam pembelajaran matematika. Dirasa mempunyai dampak positif, pembelajaran dengan cerpen matematika dilanjutkan, hingga menjadi best praktis bagi peneliti.

Penggunaan "batu" dalam pembelajaran kreatif dilakukan dengan mengkombinasikan tiga langkah kegiatan, yaitu membaca, menulis dan menguji. Membaca yang dimaksud adalah kegiatan siswa, baik secara individu maupun kelompok mempelajari, mencari dan memahami permasalahan kehidupan yang berkaitan dengan matematika. Termasuk juga membaca buku-buku paket matematika, cerpen, novel atau kisah-kisah dari layar kaca sebagai literatur penumbuhan ide.

Menulis adalah kegiatan siswa dalam merancang, mencoba, dan menulis sebuah cerpen matematika. Sedangkan kegiatan menguji, berupa kegiatan siswa untuk mengecek kesahihan permasalahan yang dibuat. Realistis dan bisa dipecahkan sendiri. Kegiatan menguji ini berjalan seiring, saat siswa melakukan kegiatan menulis. Sehingga sebelum cermat itu jadi, bahan permasalahan matematika benar-benar sudah ada solusinya. Untuk lebih menjamin kesahihan cermat, pada langkah menguji juga dilakukan dengan cara saling barter cermat, mengerjakan cermat siswa lain serta mengecek hasil pekerjaannya.

Batu Cermat ini diyakini penulis berupa pioner dalam pembelajaran matematika di SMP, sekaligus sebagai bentuk dukungan pembudayaan literasi. Hal ini berdasarkan penelusuran penulis menggunakan mesin pencari google, serta saat beraudisi dengan rekan pendidik atau pakar pendidikan pada beberapa kegiatan kependidikan. Pembelajaran matematika di SMP dengan menggunakan Batu Cermat, sepengetahuan peneliti belum ditemukan. Tetapi ada penelitian pembuatan cerpen matematika materi pecahan untuk siswa SD yang dilakukan oleh Agustiani (2016), dari penelitiannya diperoleh hasil, bahwa pembelajaran matematika dengan membuat cerita pendek dapat membantu memahami materi pecahan.

Berkaitan cerpen matematika oleh Novitasari (2012) juga sudah mengembangkannya, berdasar kesimpulannya menyatakan bahwa cerpen matematika valid, praktis dan efektif dalam menyelesaikan soal cerita pada materi kubus dan balok. Jika Novitasari (2012) sebagai pendidik membuat dan mengembangkan cerpen matematika, peneliti lebih memfokuskan siswa membuat cerpen matematika. Dengan asumsi, ketrampilan membuat cerpen sudah dikuasai dan diajarkan sejak sekolah dasar hingga duduk di bangku SMP. Pembuatan cerpen matematika di kelas yang diampu peneliti sudah diberikan contoh beserta ramburambunya serta dilatihkan di awal tahun pelajaran.

Begitu juga hasil temuan Rhosalia et al. (2016) yang melakukan penelitian berkaitan berpikir kreatif. Salah satu temuannya menyatakan bahwa, titik lemah berpikir kreatif anak terletak dari keaslian karya. Hal itu diketahui saat ketiganya melakukan penelitian berpikir kreatif anak dalam menyusun teks narasi. Untuk itulah, peneliti meletakkan keaslian sebagai salah satu indikator ketercapaian berpikir kreatif anak.

Bedanya, dalam pembelajaran yang dilakukan peneliti yaitu dengan mengkombinasikan antar materi ataupun kompetensi dasar, serta dilakukan 


\section{Abdul Hakim}

dalam bentuk kinerja ataupun projek jangka panjang. Tidak itu saja, Batu Cermat juga sebagai diversifikasi pembelajaran dan penilaian dalam implementasi kurikulum 2013. Menerapkan pendekatan scientific dengan beban belajar yang lebih ringan dan bermakna. Siswa tidak sekadar membaca, menyimak dan merangkum, tetapi sudah mampu mencipta.

\section{HASIL PENELITIAN}

\section{Rancangan Pembelajaran}

Pembuatan cerita pendek matematika (cermat) mempunyai dua bentuk.

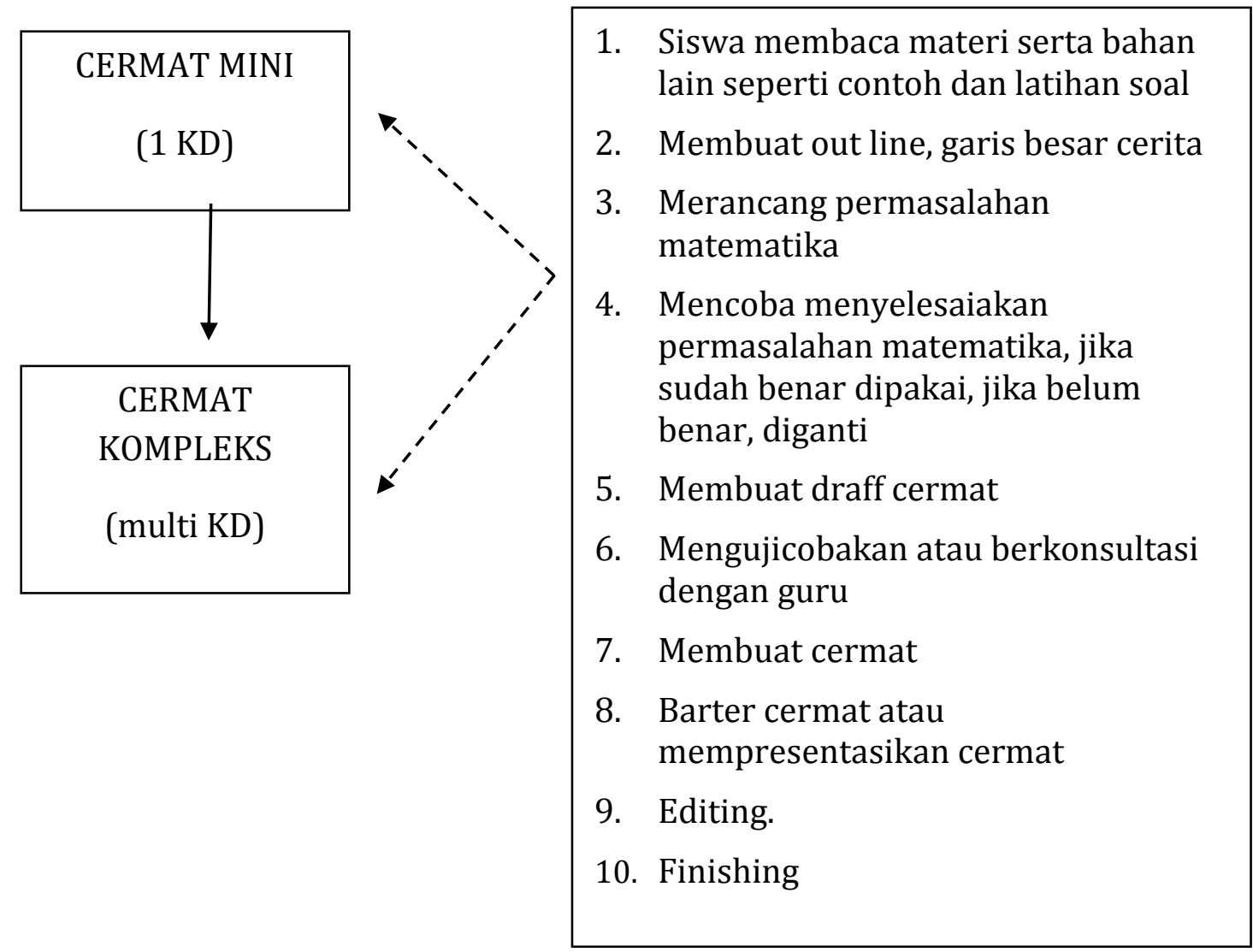

Gambar 2. Rancangan karya cermat

Penerapan pada tahap awal, siswa membuat cermat mini. Yaitu berupa cerita pendek matematika, boleh hanya satu paragraf saja. Sebagai permulaan, cermat boleh disusun dengan memodifikasi soal cerita yang ada. Soal tersebut kemudian diselesaikan sendiri oleh siswa. Guru mengecek dan memberi catatan-catatan. Tahap ini bertujuan untuk mengetahui pemahaman siswa. Bisa juga dilakukan dengan cara, setelah siswa menyusun cermat, antar siswa saling tukar cermatnya untuk dikerjakan, dan dikembalikan lagi untuk dikoreksi pembuatnya. Penerapan model ini disesuikan karakteristik kompetensi siswa.

Tahap berikutnya berupa pengembangan. Anak membuat cerita pendek (cerpen) yang terdiri lebih dari satu masalah. Sebelumnya anak disuruh merancang permasalahan matematika atau soal yang akan dimasukkan dalam 
cerpen. Masalah apa yang akan ditulis pada cerpen matematika.Tujuannya agar kelak permasalahan tersebut bisa diselesaikan. Setelah cerpen jadi, anak kembali ditugaskan mengecek, menguraikan, ataupun menganalisa sendiri masalah atau materi apa saja yang sudah dibuat dibuat. Masalah tersebut juga dibuatkan pemecahannya. Dua tahap ini bisa diterapkan dalam satu kompetensi atau satu bab yang tagihannya bisa menghasilkan penilaian ketrampilan berbentuk produk. Pelaksanaannya bisa individu, berpasangan atau berkelompok, tergantung kondisi klasikal siswa dan perencanaan guru. Alur pembelajaran dengan Batu Cermat digambarkan sebagai berikut.

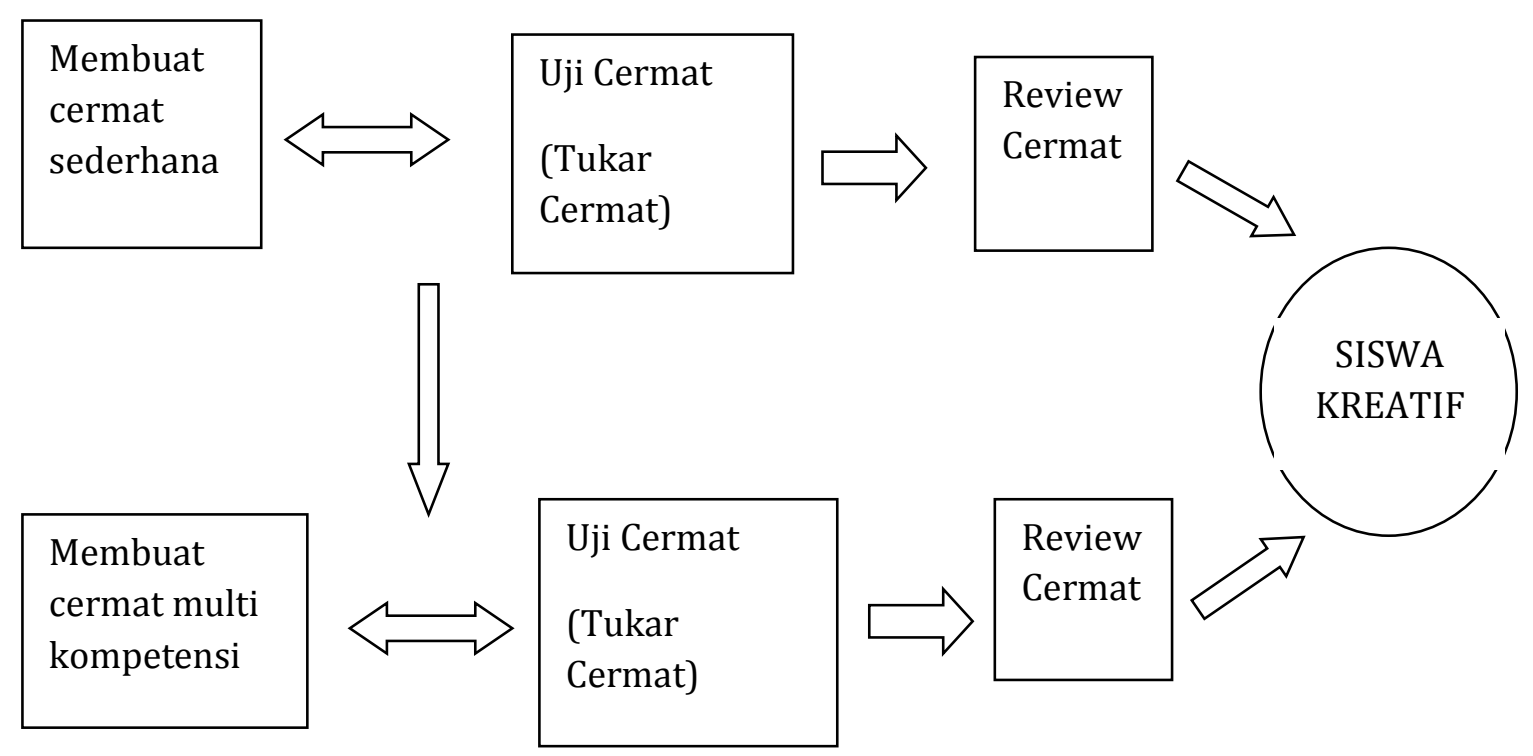

Gambar 3. Diagram Alur pembelajaran dengan Batu Cermat

Pada diagram alur itu dapat diperhatikan, bahwa proses berpikir kreatif dapat terwujud, jika diawali dari yang sederhana. Berproses, setahap demi setahap untuk mengembangkan kemampuan kreatifitas berpikir anak. Mulai membaca, tumbuh rasa ingin tahu dengan bertanya, mencari informasi untuk mencari bahan menjawab tantangan, merancang karya, mewujudkan hingga mampu menganalisa karyanya. Baik karya sendiri maupun orang lain. Guru bertindak sebagai fasilitator, memberi bimbingan seperlunya hingga anak mempunyai rasa percaya diri untuk belajar menyusun cermat. Keajegan siswa berkutat dalam membaca, memahami, menulis dan mengkritisi sebuah karya tulis, akan menumbuhkan budaya literasi di kalangan siswa.

Jika diawal pembelajaran guru sudah merangcang bentuk-bentuk penilaian ketrampilan, salah satunya bentuk kinerja, maka guru bisa menugaskan siswa membuat cermat sebagai bentuk penilaian kinerja. Karena cermat merupakan bentuk tulisan metode baru, guru memberi gambaran dan informasi yang dibutuhkan. Guru bisa seketika mengamati praktek siswa secara langsung hingga menghasilkan produk cermat. Hasil kinerja pembuatan cermat dapat diamati dari proses maupun produknya. Langkah ini efektif dilakukan bila guru menggunakan 


\section{Abdul Hakim}

alokasi waktu tiga jam pelajaran, untuk pembuatan cermat satu tema/materi atau satu kometensi dasar. Guru bisa mengamati bagaimana siswa berproses dari awal hingga akhir, melalui pembelajaran dengan pendekatan saintifik.

Cerpen matematika sederhana yang diterapkan pada satu kompetensi dasar seperti contoh berikut.
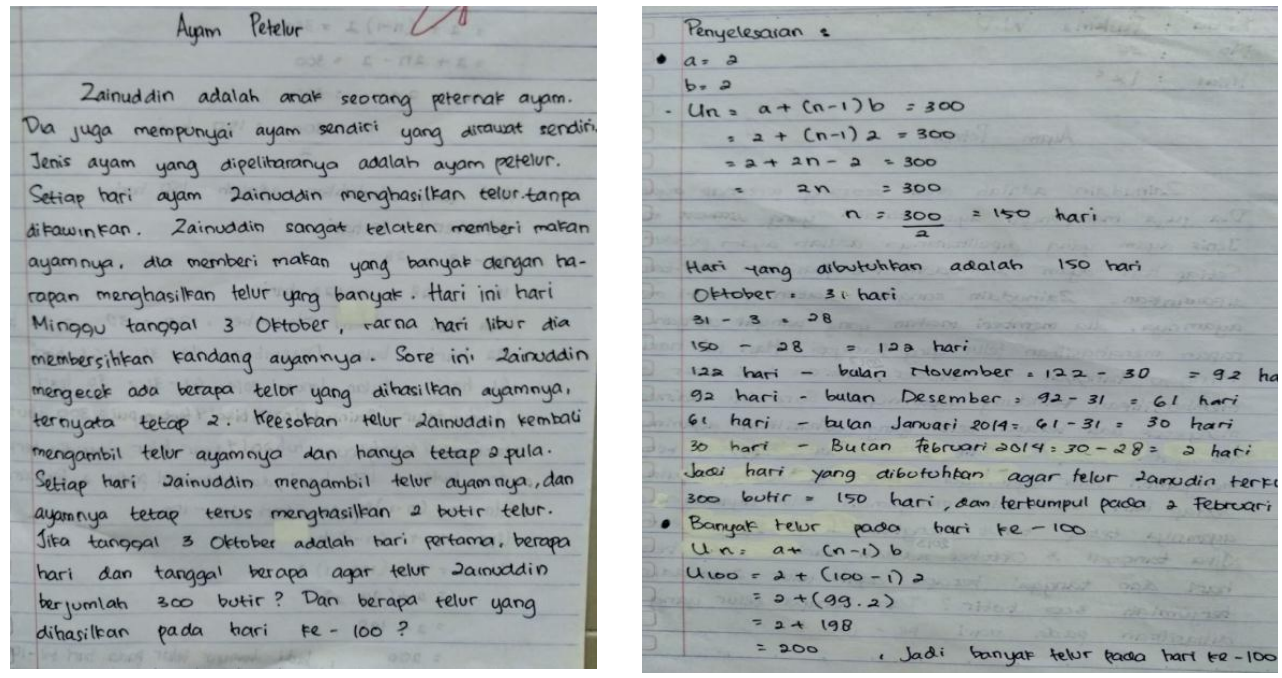

Gambar 4. Contoh cerpen matematika karya siswa satu kompetensi dasar /materi

Apabila pembuatan cermat membutuhkan waktu lebih lama, penyusunan cermat dapat dilakukan di luar jam pelajaran sebagai tugas individu berupa produk, ataupun berupa projek yang dikerjakan secara berpasangan atau kelompok. Projek sederhana dilaksanakan untuk cermat satu tema atau satu kompetensi dasar. Tentu saja cermat yang dihasilkan juga sederhana. Sedang pembuatan cermat dengan projek jangka panjang, menghasilkan karya tulis anak dalam bentuk cerita pendek yang lebih kompleks. Langkah-langkah yang dilakukan seecara berkelompok, adalah sebagai berikut.

1. Guru membentuk kelompok, banyak anggota menyesuaikan.

2. Guru memberi lembar kerja, di awal atau di pertengahan kompetensi dasar diajarkan.

3. Siswa merancang projeknya.

4. Siswa melakukan penyusunan cermat sesuai jadwal yang telah disusun.

5. Siswa bisa berkonsultasi dengan guru, baik dalam kelas atau di luar kelas.

6. Siswa melakukan presentasi ataupun saling tukar cermat untuk dikerjakan dan dianalysis hasilnya agar diperoleh umpan balik.

7. Dengan bimbingan guru, siswa melakukan editing dan finishing cermat.

Keadilan dan pengendalian setiap anak dalam kelompok diberikan juga format penilaian antar teman. Format penilaian kinerja antar teman berfokus pada beberapa indikator. Diantaranya kerjasama, kedisiplinan, sumbang saran dan keaktifan. Penilaian antar teman berfungsi sebagai pengendali proses pembuatan serta sebagai bentuk reward and punishment. 
Siswa bisa menggunakan gabungan kompetensi dasar/materi dalam satu kurun waktu panjang (satu semester misalnya) untuk menghasilkan karya sastra rasa matematika yang lebih menarik. Guru bisa mengamati perkembangan kemampuan bernalar siswa dari waktu ke waktu dan memberi masukan demi perbaikan hasil karya siswa. Perkembangan hasil kerja siswa diamati dengan rubrik. Jika mengutamakan penilaian produk, bisa dilakukan secara perorangan, sebagai salah satu cara mengembangkan dan mengukur kemampuan berpikir kreatif siswa. Hal ini juga bisa dilakukan dengan mengambil satu bab/materi atau multi materi. Dengan tahapan membuat cermat seperti di atas, jika cermat sudah mendapat umpan balik dan disempurnakan, bisa ditindaklanjuti dengan menerbitkannya dalam sebuah buku. Dalam karya tulis ini pembuatan cerpen difokuskan dalam pembutan cerpen perorangan. Hal ini dengan pertimbangan, anak-anak sejak sekolah dasar sudah terbiasa dan dianggap menguasai teori dasar membuat cerpen. Penerapan pembuatan cermat dengan berbagai cara sudah diuji dicba peneliti sebelumnya untuk mencari formula yang efektif. Pembuatan cermat secara individu berupa produk multi kompetensi dasar menjadi pegangan untuk melihat perkembangan berpikir kreatif dan budaya siswa dan menjadi titik fokus dalam artikel ilmiah ini.
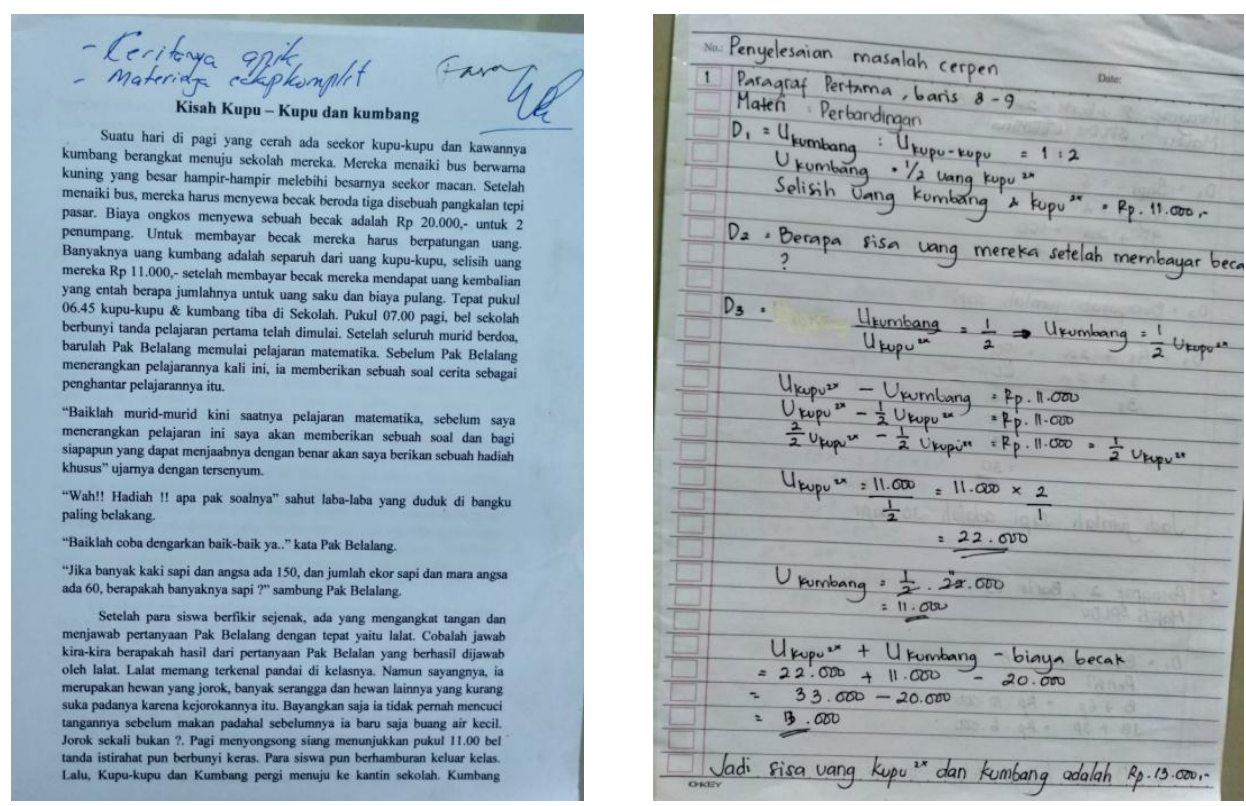

Gambar 5. Contoh soal dan jawaban cermat multi bab

\section{Pelaksanaan Pembelajaran}

Pelaksanaan pembelajaran dengan model BATU (Baca-Tulis-Uji) Cermat dilakukan seperti papaparan di bawah ini.

a. Membaca 


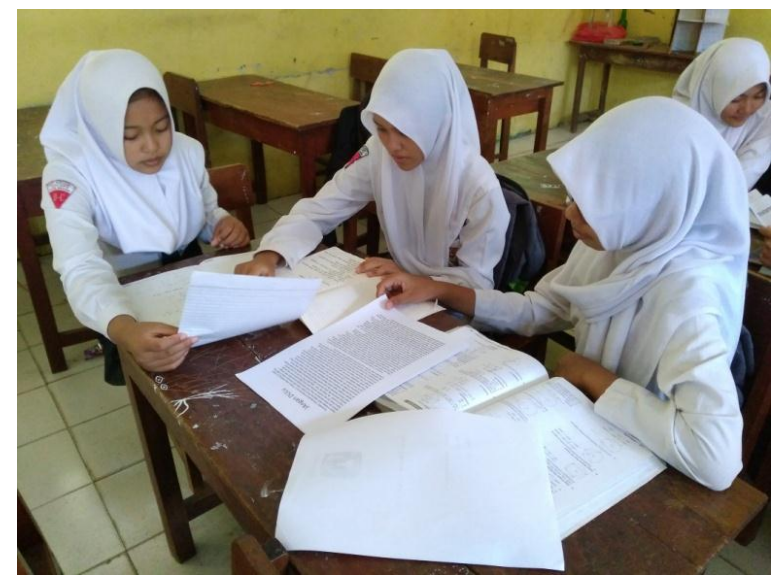

Gambar 6. Kegiatan membaca siswa

Pada tahap ini siswa belajar mengenal cermat dengan terlebih dahulu membaca bahan. Baik itu berupa soal cerita matematika dari buku paket ataupun dan sumber lain. Dengan membaca, siswa mempunyai tambahan pengetahuan, ide serta bahan untuk menyusun cerpen matematika. Termasuk juga materi matematika yang akan dimasukkan.

\section{b. Menulis}

Kegiatan menulis siswa dapat dilakukan pada jam pelajaran di kelas atau di luar jam pelajaran. Di kelas, guru bisa memberikan bimbingan bila siswa mengalami kesulitan. Pembimbingan juga bisa dilakukan di luar jam pelajaran, baik interaksi langsung maupun melalui jaringan sosial media.

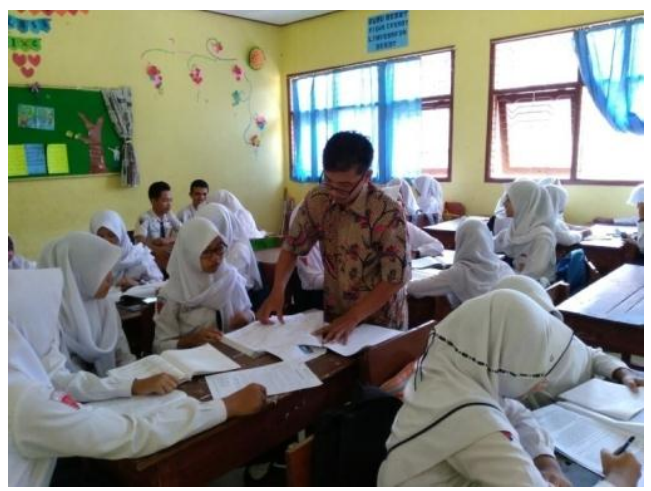

Gambar 7. Guru memberi pembimbingan saat siswa menulis cermat

\section{c. Menguji}

Hasil pembuatan cermat diuji kesahihannya dengan melakukan saling tukar pekerjaan. Dikerjakan secara berkelompok. Guru mengecek hasil pekerjaan awal dan hasil pekerjaan yang telah dikoreksi, dengan terlebih dahulu dikoreksi oleh penyusun cermat. 


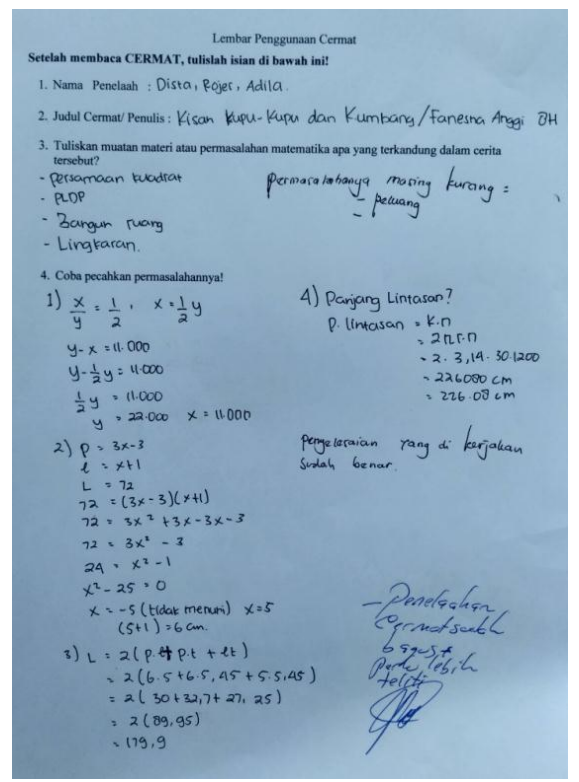

Gambar 8. Hasil pengujian cermat

Umpan balik dilakukan dengan mempresentasikan beberapa cermat di depan kelas. Siswa pembuat cermat memaparkan karyanya. Siswa lain menanggapi, baik dari sisi tulisan maupun muatan matematika.

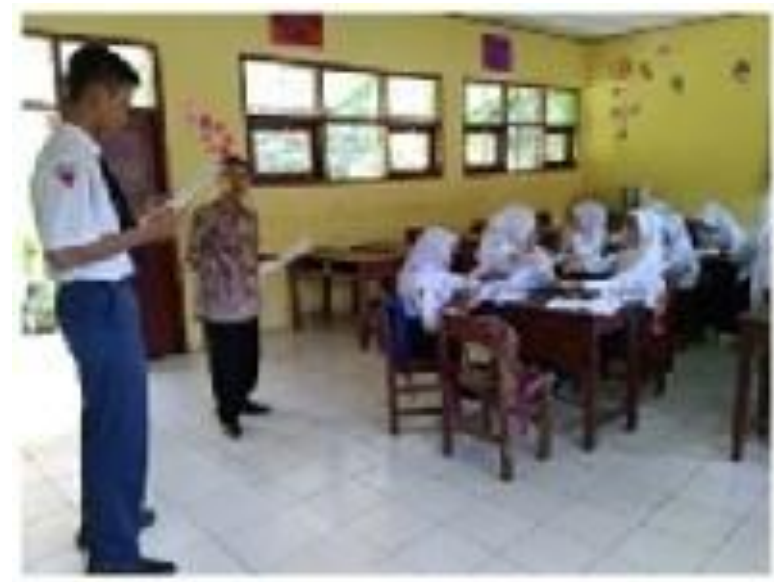

Gambar 9. Siswa mempresentasikan cermat di depan kelas

Kesahihan diuji dengan cara melihat kreatifitas serta daya kritis anak, siswa lain menunjukkan kemampaun dalam menelaah cermat lain untuk disandingkan dan dianalisa kembali oleh pembuatnya. Apakah cermat yang disusun benar dan hasil kajian yang dibuat sesuai dengan yang dirancang pemnyusun cermat. Guru mengamati jalannya diskusi serta mereview hasil diskusi. 


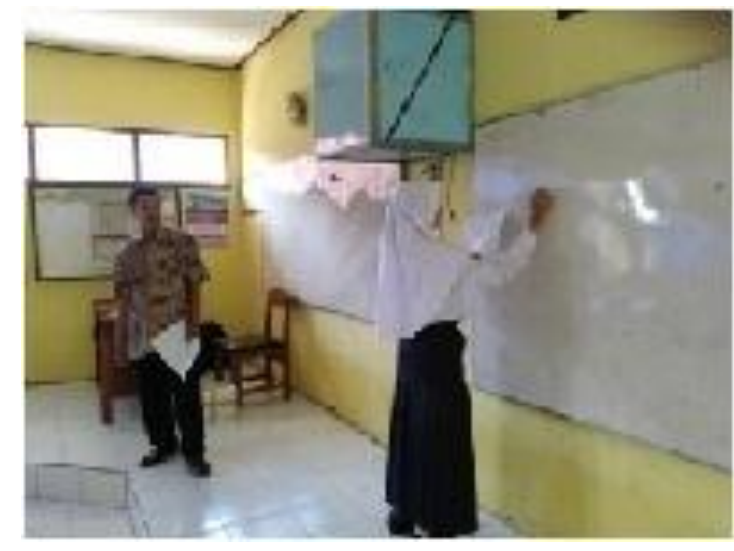

Gambar 10. Menguji karya cermat siswa lain

\section{HASIL APLIKASI PEMBELAJARAN}

Data yang diperoleh berupa nilai pembuatan cerpen matematika siswa SMP negeri 1 Dolopo Kabupaten Madiun, selama tiga tahun pelajaran, 2015/2016, 2016/2017, dan tahun pelajaran 2017/2018. Nilai diambil dari produk cerpen pada setiap akhir semester gasal dan genap. Data awal saat masih membuat cerpen satu kompetensi dasar, digunakan peneliti untuk mengetahui kemampuan dasar anak membuat cermat. Selanjutnya diberikan pengarahan dan masukan sebagai bahan pembuatan cermat multi kompetemsi dasar, yang dikumpulkan di akhir semester.

Pada tahun pelajaran 2015/2016, peneliti mengajar 5 kelas. Tiga puluh dua anak kelas VII D yang terdiri 12 siswa laki-laki dan 20 siswa perempuan, kelas VII E 32 anak, terdiri 12 siswa laki-laki dan 20 siswa perempuan, kelas VIII C 31 anak terdiri 5 siswa laki-laki dan 26 siswa perempuan, kelas IX C 32 anak yang terdiri 12 siswa laki-laki dan 20 siswa perempuan, serta kelas IX D 30 anak yang terdiri 11 siswa laki-laki dan 19 siswa perempuan. Capaian pembuatan cermat seperti tabel di bawah ini.

Tabel 2. Nilai Cerpen matematika tahun pelajaran 2015/2016

\begin{tabular}{|c|c|c|c|c|c|c|c|c|c|c|c|}
\hline \multirow{3}{*}{ NO. } & \multirow{3}{*}{ URAIAN } & \multicolumn{10}{|c|}{ CAPAIAN HASIL PEMBUATAN CERMAT } \\
\hline & & \multicolumn{2}{|c|}{ VII D } & \multicolumn{2}{|c|}{ VII E } & \multicolumn{2}{|c|}{ VIII C } & \multicolumn{2}{|c|}{ IX C } & \multicolumn{2}{|c|}{ IX D } \\
\hline & & $\mathrm{I}$ & II & $\mathrm{I}$ & II & $\mathrm{I}$ & II & $\mathrm{I}$ & II & $\mathrm{I}$ & II \\
\hline 1 & $\begin{array}{l}\text { Keunikan / keaslian } \\
\text { cerita }\end{array}$ & 70 & 75 & 70 & 80 & 75 & 92 & 78 & 91 & 73 & 85 \\
\hline 2 & $\begin{array}{l}\text { Alur } \\
\text { cerita/keterhubungan } \\
\text { materi cerita }\end{array}$ & 70 & 77 & 71 & 73 & 71 & 85 & 73 & 84 & 67 & 79 \\
\hline
\end{tabular}


Penggunaan Batu Cermat dalam Mengembangkan Kemampuan....

\begin{tabular}{|c|c|c|c|c|c|c|c|c|c|c|c|}
\hline \multirow{3}{*}{ NO. } & \multirow{3}{*}{ URAIAN } & \multicolumn{10}{|c|}{ CAPAIAN HASIL PEMBUATAN CERMAT } \\
\hline & & \multicolumn{2}{|c|}{ VII D } & \multicolumn{2}{|c|}{ VII E } & \multicolumn{2}{|c|}{ VIII C } & \multicolumn{2}{|c|}{ IX C } & \multicolumn{2}{|c|}{ IX D } \\
\hline & & $\mathrm{I}$ & II & $\mathrm{I}$ & II & $\mathrm{I}$ & II & $\mathrm{I}$ & II & $\mathrm{I}$ & II \\
\hline 3 & Kreatifitas menulis & 73 & 74 & 70 & 76 & 69 & 86 & 73 & 80 & 65 & 78 \\
\hline 4 & $\begin{array}{l}\text { Kemampuan } \\
\text { Identifikasi materi }\end{array}$ & 66 & 73 & 68 & 73 & 68 & 85 & 70 & 80 & 61 & 75 \\
\hline 5 & $\begin{array}{l}\text { Langkah-langkah } \\
\text { penyelesaian }\end{array}$ & 54 & 66 & 55 & 68 & 60 & 76 & 61 & 69 & 54 & 59 \\
\hline & Rata-rata & 67 & 73 & 67 & 74 & 69 & 85 & 71 & 81 & 64 & 73 \\
\hline
\end{tabular}

Tahun pelajaran 2016/2017, peneliti juga mengajar 5 kelas. Kelas VII F 32 siswa yang terdiri 13 siswa laki-laki dan 19 siswa perempuan, kelas VIII H 32 anak, yang terdiri 14 siswa laki-laki dan 18 siswa perempuan, kelas VIII I 32 anak, yang terdiri 13 siswa laki-laki dan 19 siswa perempuan, kelas VIII J 32 anak yang terdiri 13 siswa laki-laki dan 19 siswa perempuan, serta kelas IX C 31 anak yang terdiri 5 siswa laki-laki dan 26 siswa perempuan. Capaian pembuatan cermat seperti tabel di bawah ini.

Tabel 3. Nilai Cerpen matematika tahun pelajaran 2016/2017

\begin{tabular}{|c|c|c|c|c|c|c|c|c|c|c|c|}
\hline \multirow{3}{*}{ NO. } & \multirow{3}{*}{ URAIAN } & \multicolumn{10}{|c|}{ CAPAIAN HASIL PEMBUATAN CERMAT } \\
\hline & & \multicolumn{2}{|c|}{ VII F } & \multicolumn{2}{|c|}{ VIII H } & \multicolumn{2}{|c|}{ VIII I } & \multicolumn{2}{|c|}{ VIII J } & \multicolumn{2}{|c|}{ IX C } \\
\hline & & I & II & I & II & $\mathrm{I}$ & II & $\mathrm{I}$ & II & $\mathrm{I}$ & II \\
\hline 1 & $\begin{array}{l}\text { Keunikan / keaslian } \\
\text { cerita }\end{array}$ & 73 & 89 & 72 & 84 & 79 & 88 & 77 & 88 & 81 & 96 \\
\hline 2 & $\begin{array}{l}\text { Alur } \\
\text { cerita/keterhubungan } \\
\text { materi cerita }\end{array}$ & 76 & 86 & 72 & 80 & 70 & 84 & 72 & 85 & 80 & 89 \\
\hline 3 & Kreatifitas menulis & 77 & 83 & 65 & 81 & 66 & 84 & 65 & 94 & 81 & 95 \\
\hline 4 & $\begin{array}{l}\text { Kemampuan } \\
\text { Identifikasi materi }\end{array}$ & 72 & 80 & 70 & 84 & 64 & 80 & 66 & 81 & 77 & 92 \\
\hline 5 & $\begin{array}{l}\text { Langkah-langkah } \\
\text { penyelesaian }\end{array}$ & 59 & 72 & 59 & 79 & 55 & 76 & 59 & 75 & 60 & 77 \\
\hline & Rata-rata & 71 & 82 & 67 & 82 & 67 & 83 & 68 & 85 & 76 & 90 \\
\hline
\end{tabular}

Sedang untuk tahun pelajaran 2017/2018, peneliti mengajar di kelas IX I terdiri dari 32 anak, 10 laki-laki dan 22 perempuan. Kelas IX J, 32 anak terdiri dari 12 laki-laki dan 20 perempuan, kelas VIII D 32 anak, terdiri dari 13 laki-laki 19 perempuan, Kelas VIII E 32 anak, terdiri dari 13 laki-laki dan19 perempuan, dan kelas VII H 32 anak terdiri dari 16 laki-laki serta 16 perempauan. Adapun data nilai disajikan pada tabel di bawah ini. 
Tabel 4. Nilai Cerpen matematika tahun pelajaran 2017/2018

NO.

URAIAN

CAPAIAN HASIL PEMBUATAN CERMAT

\begin{tabular}{|c|c|c|c|c|c|c|c|c|c|c|c|}
\hline & \multirow{2}{*}{ 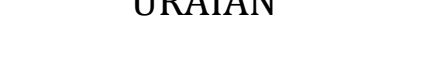 } & \multicolumn{2}{|c|}{ VIII } & \multicolumn{2}{|c|}{ VIIID } & \multicolumn{2}{|r|}{ L } & \multicolumn{2}{|c|}{$1 / 1$} & \multicolumn{2}{|c|}{ (n) } \\
\hline & & $\mathrm{I}$ & II & $\mathrm{I}$ & II & $\mathrm{I}$ & II & I & II & $\mathrm{I}$ & II \\
\hline 1 & $\begin{array}{l}\text { Keunikan / keaslian } \\
\text { cerita }\end{array}$ & 60 & 91 & 70 & 94 & 70 & 97 & 70 & 98 & 75 & 98 \\
\hline 2 & $\begin{array}{l}\text { Alur } \\
\text { cerita/keterhubungan } \\
\text { materi cerita }\end{array}$ & 60 & 83 & 75 & 80 & 65 & 83 & 75 & 87 & 70 & 88 \\
\hline 3 & Kreatifitas menulis & 70 & 81 & 70 & 88 & 75 & 87 & 70 & 90 & 70 & 91 \\
\hline 4 & $\begin{array}{l}\text { Kemampuan } \\
\text { Identifikasi materi }\end{array}$ & 60 & 77 & 65 & 80 & 70 & 75 & 65 & 81 & 65 & 88 \\
\hline 5 & $\begin{array}{l}\text { Langkah-langkah } \\
\text { penyelesaian }\end{array}$ & 50 & 72 & 70 & 71 & 60 & 72 & 50 & 72 & 70 & 74 \\
\hline & Rata-rata & 60 & 81 & 70 & 83 & 68 & 83 & 66 & 88 & 70 & 91 \\
\hline
\end{tabular}

Sebagai bahan pendamping untuk melihat kebermaknaan Batu Cermat, peneliti memberikan angket. Butir pertanyaan angket siswa ditujukan untuk mengetahui kebaruan Batu Cermat serta hubungannya terhadap kebermanfaatan serta dampaknya terhadap minat membaca, menulis dan berpikir siswa. Data angket siswa yang diambil datanya dari siswa yang diampu peneliti pada tahun pelajaran 2017/2018 diperoleh hasil seperti pada tabel di bawah ini.

Tabel 5. Rekapitulasi angket Batu Cermat

\begin{tabular}{clcccc}
\hline \multirow{2}{*}{ NO. } & \multicolumn{1}{c}{ BUTIR ANGKET } & \multicolumn{2}{c}{ JUMLAH } & \multicolumn{2}{c}{ PROSENTASE } \\
\cline { 3 - 6 } & $\begin{array}{c}\text { SANGAT } \\
\text { SETUJU }\end{array}$ & SETUJU & $\begin{array}{c}\text { SANGAT } \\
\text { SETUJU }\end{array}$ & SETUJU \\
\hline 1 & $\begin{array}{l}\text { Cerpen matematika itu model } \\
\text { cerpen yang baru saya ketahui }\end{array}$ & 150 & 10 & 94 & 6 \\
2 & 125 & 35 & 78 & 22 \\
$\begin{array}{l}\text { Belajar membuat cerpen } \\
\text { matematika itu menyenangkan }\end{array}$ & 122 & 38 & 76 & 24 \\
$\begin{array}{l}\text { Cermat mempermudah saya } \\
\text { memahami materi matematika }\end{array}$ & 116 & 44 & 73 & 28 \\
$\begin{array}{l}\text { Cermat membuat saya percaya } \\
\text { diri mengerjakan soal-soal } \\
\text { matematika }\end{array}$ & $\begin{array}{l}\text { Cermat membuat saya semakin } \\
\text { senang membaca dan menulis } \\
\text { Cermat membuat saya lebih }\end{array}$ & 112 & 48 & 70 & 30 \\
$\begin{array}{l}\text { tahu manfaat belajar } \\
\text { matematika }\end{array}$ & 34 & 79 & 21 \\
\hline
\end{tabular}




\section{PEMBAHASAN}

Data yang diperoleh, diolah rata-ratanya untuk setiap unsur yang dinilai. Adapun unsur dan hasil rata-ratanya tertera pada tabel rekapitulasi di bawah ini. Untuk melihat rata-rata perkembangan kemampuan berpikir kreatif anak dengan melihat peningkatan minimal $10 \%$ dari pembuatan cermat sebelumnya. Sedangkan budaya literasi diukur dari kemampuan anak membuat cermat dengan baik yang ditandai dengan terhimpunnya cermat karya siswa dan terdokumentasi dalam bentuk buku.

Tabel 6. Capaian rata-rata cerpen matematika tahun 2015/2016, 2016/2017 dan $2017 / 2018$

\begin{tabular}{|c|c|c|c|c|c|c|c|}
\hline \multirow{3}{*}{ NO. } & \multirow{3}{*}{ URAIAN } & \multicolumn{6}{|c|}{ CAPAIAN HASIL PEMBUATAN CERMAT } \\
\hline & & \multicolumn{2}{|c|}{$2015 / 2016$} & \multicolumn{2}{|c|}{$2016 / 2017$} & \multicolumn{2}{|c|}{$2017 / 2018$} \\
\hline & & I & II & I & II & I & II \\
\hline 1 & Keunikan / keaslian cerita & 73 & 85 & 76 & 89 & 69 & 96 \\
\hline 2 & $\begin{array}{l}\text { Alur cerita/keterhubungan } \\
\text { materi cerita }\end{array}$ & 70 & 80 & 74 & 85 & 69 & 84 \\
\hline 3 & Kreatifitas menulis & 70 & 79 & 71 & 87 & 71 & 87 \\
\hline 4 & Kemampuan identifikasi materi & 67 & 77 & 70 & 83 & 65 & 80 \\
\hline \multirow[t]{2}{*}{5} & Langkah-langkah penyelesaian & 57 & 68 & 58 & 76 & 60 & 74 \\
\hline & Rata-rata & 68 & 77 & 70 & 84 & 67 & 85 \\
\hline
\end{tabular}

Berdasarkan data pada tabel 5 di atas bisa diketahui beberapa hal. Keunikan dan keaslian skor naik 15,6 \%, 16,5 \% dan 38,6\%. Artinya, anak berusaha untuk membuat cermat yang benar-benar sesuai idenya sendiri. Setiap periode terjadi kenaikan cukup baik dalam pembuatan cermat. Dari sebelumnya membuat asal-asalan dan me-replace karya hasil copy paste dari dunia maya, berubah menjadi karya ide sendiri. Meski masih banyak cermat anak ini terlihat lugu dan sederhana. Lebih baik sederhana tetapi karya sendiri, daripada kelihatan baik, ternyata melakukan plagiasi. Hal ini menunjukkan tingkat kejujuran dan kreatifiatas tinggi.

Alur cerita dalam cermat skornya naik 13,1\%, 14,66\% dan 22,0\%. Salah satu hal tersulit dalam membuat cermat adalah membuat alur cerita yang mengalir. Bukan cerita patah- patah, atau kumpulan soal cerita matematika yang ditempel dan dipaksakan. Tetapi dengan belajar dan pembimbingan, karya anak-anak mulai tertata apik, menjadi sebuah jalinan cerita yang enak dibaca. Hal ini menunjukkan, kreatifitas berpikir anak berkembang pesat. Sebuah tulisan butuh ide kreatif agar suatu cermat bisa dinikmati dengan baik. Kreatifitas ini dilihat dari karya anak, bagaimana mengolah sebuah kisah yang lain dari biasanya, tidak monoton dan dirasa menumbuhkan keingintahuan pembaca.

Kreatifitas menulis naik $12,6 \%, 23,4 \%$ dan $23,1 \%$. Kreatifias menulis yang menjadi pegangan peneliti meliputi cara penyajian penokohan, setting dan ide. Sesuai dengan perkembangan usia dan kemajuan teknologi, ide-ide mereka banyak dipengaruhi ide dari berbagai sumber. Baik dari film, sinetron dan informasi lain 
dari internet. Kebuntuan anak saat membuat cermat bisa diatasi jika anak banyak membaca, mendengar atau melihat media informasi. Berdasar capaian anak, kemampuan mereka meningkat dan semakin terasah.

Kemampuan identifikasi materi, naik 15,9\%, 19,5\% dan 23,4\%. Mengalami kenaikan cukup tinggi. Hal ini karena mereka sudah merancang permasalahan dengan baik sebelum cermat tersusun. Sehingga cermat yang dibuat mudah disisipkan dan diungkap kembali. Hal ini cukup dipengaruhi oleh perancangan pembuatan cermat. Jika di awal siswa sudah membuat outline, menyiapkan permasalahan matematika dan sudah mengujinya terlebih dahulu, identifikasi masalah dalam cermat mudah disusun.

Kemampuan memecahkan masalah mengalami kenaikan cukup tinggi, 19,0\%, 29,8\% dan 20,3\%. Hal ini menunjukkan, bahwa mereka sudah berhasil memecahkan masalah dari masalah yang mereka ciptakan sendiri. Anak-anak sudah mampu membuat masalah, mengintegrasikan serta mampu memecahkan masalah sendiri, yang merupakan bentuk kreatifitas berpikir yang cukup kompleks.

Dilihat dari capaian kreatifitas berpikir siswa, dapat diperhatikan pada tabel di bawah ini.

Tabel 7. Capaian kreatifitas berpikir siswa tahun 2015/2016, 2016/2017 dan $2017 / 2018$

\begin{tabular}{cccccccc}
\hline \multirow{3}{*}{ Rentang Nilai } & Tingkat berpikir kreatif & \multicolumn{5}{c}{ Banyak anak } \\
\cline { 3 - 7 } & & \multicolumn{2}{c}{$2015 / 2016$} & $2016 / 2017$ & $2017 / 2018$ \\
\cline { 3 - 7 } & Sangat kreatif & 0 & 13 & 0 & 32 & 0 & 30 \\
\hline $91-100$ & Kretif & 1 & 31 & 5 & 71 & 0 & 76 \\
$81-90$ & Cukup kreatif & 87 & 105 & 88 & 56 & 60 & 54 \\
$70-80$ & Kurang kreatif & 69 & 8 & 66 & 0 & 100 & 0 \\
$<70$ & Jumlah & 157 & 157 & 159 & 159 & 160 & 160 \\
\hline
\end{tabular}

Berdasar kriteria yang ditetapkan sebelumnya, dari tabel 7 dapat diketahui siswa yang berkembang tingkat berpikir kreatifnya. Tahun pelajaran 2015/2016, siswa yang kreatifnya berkembang, dari 1 siswa (0,6\%) naik menjadi 44 siswa (28\%). Tahun pelajaran 2016/2017, dari 5 siswa (3\%) pada semester gasal, berkembang menjadi 103 siswa (65\%) di semester genap. Tahun pelajaran $2017 / 2018$, dari belum adanya siswa yang berkembang di semester gasal, menjadi 106 siswa (66\%) pada semester genap.

Tingkat perkembangan berpikir kreatif pada tahun 2015/2016 memang masih rendah. Periode ini memang tahap awal peneliti menerapkan batu cermat. Peneliti masih mencari format yang lebih tepat sekaligus penjajagan kompetensi anak pada literasi. Pada periode ini, diketahui pula bahwa siswa budaya bacanya kurang. Oleh karena peneliti mengajak siswa untuk gemar membaca. Baik di perpustakaan maupun membaca buku-buku berupa e-book serta bahan bacaan yang tersedia di dunia maya. 
Sedangkan pada dua tahun pelajaran berikutnya penerapan batu cermat sudah menunjukkan hasil. Lebih dari 50\% siswa mampu mengembangkan berpikir kreatifnya. Terutama untuk kelas yang dua tahun peneliti ampu. Hanya saja, untuk semester gasal tahun pelajaran 2017/2018, karena peneliti ada tugas in dan on implementasi kurikulum 2013 sebagai instruktur kurikulum 2013 Kabupaten Madiun, frekuensi pertemuan tidak efektif. Dampaknya pendampingan pembuatan cermat tidak optimal. Akibatnya, kualitas cermat tidak baik. Kreatifitas berpikir siswa kurang berkembang. Tetapi pada semester genap 2017/2018, kemampuan berpikir kreatif siswa berkembang cukup baik.

Berdasar data-data di atas juga bisa diketahui, ada beberapa kelas yang mengalami perkembangan peningkatan cukup baik, yaitu kelas VIII C pada tahun 2015/2016 dan IX C pada tahun 2016/2017, kelas VIII I dan VIII J tahun 2016/2017 serta kelas IX I dan IX J tahun 2017/2018. Ketiga kelas tersebut selama dua tahun berturut-turut peneliti ajar. Siswa mulai paham dan lebih terampil membuat cerpen matematika. Hal ini menunjukkan, semakin sering menulis itu dilatih akan semakin baik hasilnya. Sekaligus menunjukkan, bahwa jika ketrampilan menulis sebagai bagian literasi semakin membudaya dalam diri siswa.

Sedang dari hasil angket diperoleh bahwa pembelajaran Batu cermat merupakan model cerpen yang baru pertama kali mereka kenal dan buat (94\%). Sesuatu yang baru merupakan modal dasar untuk membuat anak penasaram dan merangsang anak untuk mencoba. Meski membuat cerpen dalam Bahasa Indonesia sudah biasa dilakukan, namun untuk cerpen matematika masih menjadi menjadi beban dan cukup menyenangkan. Hal ini terlihat dari $78 \%$ anak merasa cukup senang membuat cermat. Termasuk juga, $24 \%$ anak masih belum merasa, bahwa dengan cermat bisa mempermudah belajar matematika. Bisa jadi hal ini dikarenakan ada trauma sebelumnya, yang sering menganggap matematika itu mata pelajaran sulit.

Kepercayaan diri anak untuk belajar matematika setelah belajar dengan batu cermat dalam klasifikasi cukup baik (73\%). Kepercayaan diri ini timbul dimungkinkan karena siswa sudah terlatih membuat dan memecahkan permasalahan matematika. Sementara budaya literasi mulai tampak dan berkembang yang didukung data 70\% siswa mulai gemar membaca dan menulis. Yang cukup membahagiakan, 79\% anak semakin tahu kemanfaatan matematika. Dengan tahu manfaat matematika, hal ini sebagai stimulus bagi mereka untuk belajar matematika lebih giat.

Berdasar keterangan di atas dan kajian pustaka menurut Agustina dam Edy Surya, hal ini sudah bisa untuk menyatakan bahwa dengan menerapkan pembuatan cerpen matematika mampu mengembangkan kemampuan berpikir kreatif siswa. Siswa bisa merancang sebuah permasalahan dengan berbagai versi cerita dari berbagai kompetensi dasar yang mereka pelajari. Untuk satu kompetensi dasar atau untuk satu materi saja, misalnya barisan bilangan, dari beberapa anak, cara menyajikan, yang dipermasalahkan dan cara menyelesaikan juga berbeda.

Salah satu yang sangat membahagiakan peneliti adalah, anggapan bahwa menulis cerpen, khususnya yang berupa cerpen matematika bukan sesuatu yang tidak mungkin. Jika semula, sebagian besar anak menganggap menyusun cermat itu sulit, tetapi dengan contoh, bimbingan dan motivasi, semua anak mampu 
membuatnya. Hal ini sebagai salah bentuk gerakan pengembangan pembudayaan literasi. Matematika yang identik dengan angka dan garis, ternyata bisa disulap menjadi bentuk karya sastra lain, yang mungkin saja belum banyak dibuat orang lain.

Pembelajaran dengan Batu Cermat ini mempunyai kelebihan dalam menggali dan mengembangkan potensi anak. Disamping mengembangkan kreatifitas berpikir, juga memotivasi anak untuk lebih suka membaca dan menulis. Dari karya anak-anak yang terkumpul, dari perkiraan hanya bisa membuat cermat kurang dari sepuluh halaman, ternyata banyak yang bisa membuat cermat menyerupai novelet, novel mini.

Tidak itu saja, faktanya anak-anak ini jika diwadahi dan dirangsang berkarya bisa mengeluarkan imajinasinya bak pujangga. Cermat mereka mempunyai variasi cerita dengan gaya-gaya unik dan menggoda sesuai dengan jiwa remaja. Siswa yang semula diperintah membaca, ketagihan, bahkan pada akhirnya hoby menulis. Tidak hanya karena ada tugas, tetapi seperti menjadi ketagihan. Siswa-siswa mulai suka menulis di platform digital, wattapad, misalnya serta berani mengirim karya ke media. Baik media cetak, digital, juga berkompetisi menulis. Termasuk berkompetisi dengan peneliti yang juga sebagai penulis. Meski sebagai guru matematika, peneliti acap kali menjadi tempat berkonsultasi terhadap karya tulis siswa. Bukti, Batu Cermat bisa menjadi jembatan dalam membudayakan virus literasi di kalangan anak sekolah.

Dilihat dari sisi penilaian, peneliti memang mencoba membuat efektifitas penilaian ketrampilan. Untuk cermat multi kompetensi dasar, hasil penilaiannya bisa dimasukkan ke seluruh materi atau kompetensi dasar pada kelas dan semester yang berlaku. Tentu saja guru sudah harus membuat kesepakatan dan rambu-rambu penilaian dan disampaikan di awal semester.

Sudah barang tentu, sebuah gagasan baru pasti ada kendala dan kelemahan. Bagi anak yang tidak telaten membaca dan menulis, kadang kala mengambil jalan pintas dengan melakukan plagiasi. Mencopy paste cerita-cerita yang ada di dunia maya. Termasuk juga bagi anak yang memang dari awal lemah penguasaan materi matematika. Untuk hal ini guru tidak boleh kalah dengan siswa. Mesin pencari bisa dipakai untuk melihat karya-karya yang dicurigai hasil plagiat. Dari sisi guru, jika guru tidak melek literasi, juga menjadi kendala awal untuk mempraktekkannya.

Sebagai bentuk penghargaan dan prasasti atas karya siswa ini, cermat telah diterbitkan dalam 4 (empat) buku ber_ISBN, berjudul An Antologi Math Story : The Art Of Math (Hakim \& Friends, 2017a), Cinta Bertabur Logika (Hakim \& Friends, 2017b), Cinta di Balik Angka (Hakim \& Friends, 2017c), dan The Amazing of love (Hakim \& et al., 2018), yang covernya seperti gambar 11 di bawah ini. 


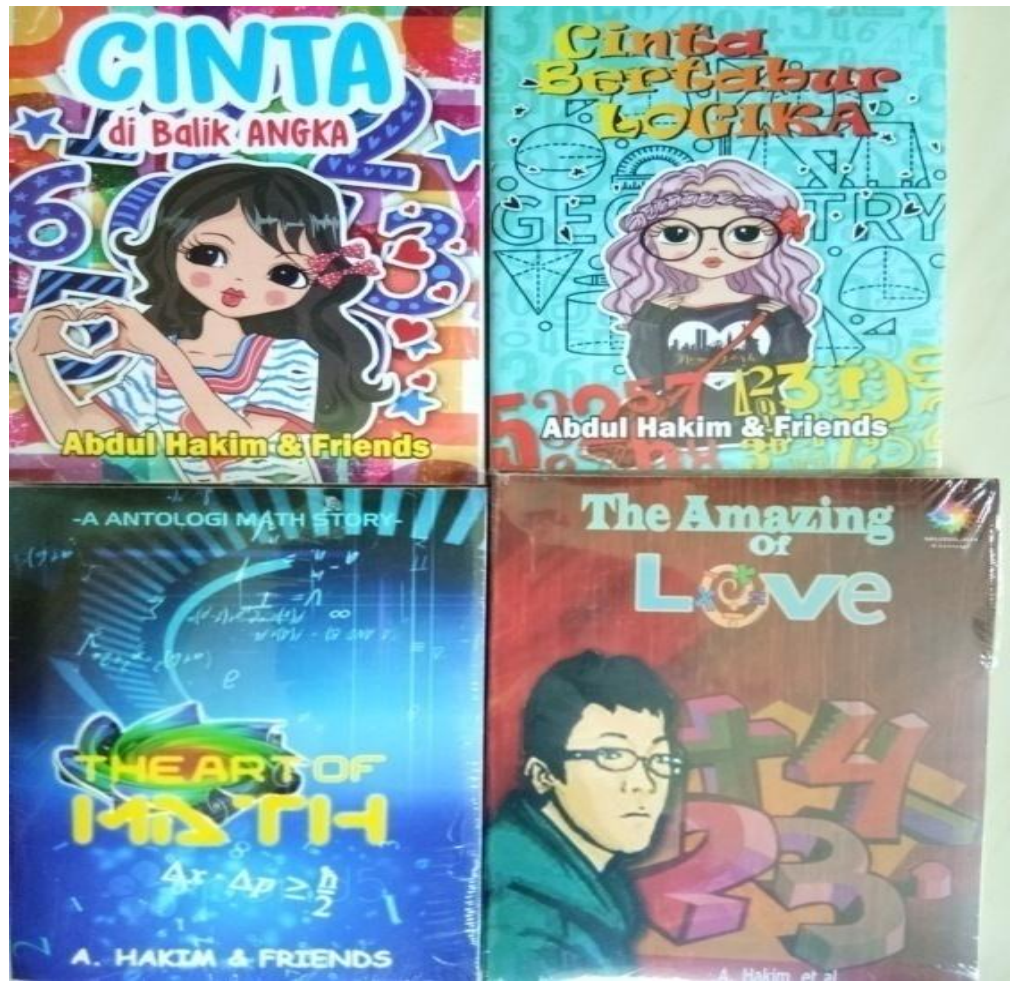

Gambar 11. Cover buku cerpen matematika yang telah terbit

Buku-buku ini bebas dimiliki oleh siapapun serta disimpan di perpustakaan sekolah. Dengan diterbitkannya karya mereka, dapat menumbuhkan kebanggaan dan semangat untuk berkarya lebih lanjut. Minimal, nama mereka akan abadi dalam kenangan penerus generasi negeri ini.

\section{KESIMPULAN DAN SARAN}

Batu Cermat merupakan bentuk inovasi baru dalam pembelajaran. Dengan pembiasaan, fasilitasi dan motivasi sesuatu yang baru justru menciptakan suasana dan ketrampilan baru. Terbukti dari data yang diperoleh selama pembelajaran menggunakan Batu Cermat, kreatifitas berpikir anak tumbuh berkembang. Dengan semakin terampilnya anak membuat cerpen matematika, hal ini juga ikut menggerakkkan budaya literasi, utamanya budaya memabaca dan menulis bagi siswa.

Mensastrakan matematika dalam bentuk cerpen, akan mampu memotivasi siswa untuk lebih giat belajar matematika. Hal ini juga menunjukkan bahwa, matematika itu indah, unik dan menarik, asal saja dikemas dengan apik dan bercita rasa seni.

Cerpen matematika ini masih hal baru dalam dunia sastra. Perlu pemahaman dan kerja sama antara guru matematika dan guru Bahasa Indonesia. Dengan bersinergi, tidak hanya guru, siswa juga terbantu dalam pemenuhan kewajiban siswa sebagai peserta didik. Penulisan cermat juga sebagai bentuk dukungan dalam gerakan literasi. Asal ada kemauan pasti ada jalan. Pembuatan cermat lebih mudah dilakukan dengan banyak membaca literatur. Langkah awal dapat 
dilakukan dengan memodifikasi cerpen yang sudah ada. Baik dari buku atau digital. No plagiat.

Membelajarkan cermat tidak cukup sekadar memberi tugas. Guru matematika juga harus memberi teladan. Caranya, guru juga harus bisa membuat cerpen matematika buatan guru sendiri. Mengoptimalkan Musyawarah Guru Mata Pelajaran Sekolah (MGMPS) di sekolah untuk berlatih dan berbagi. Melakukan lesson study di sekolah untuk saling belajar dengan rekan sejawat yang menggunakan cermat. Guru matematika mencoba membuat cermat sendiri dan mempraktekkannya di kelas yang diampu. Kepada siswa, untuk tahap awal dipilihkan materi atau kompetensi dasar yang mudah. Memodifikasi cerpen yang sudah ada, dengan memasukkan materi matematika di dalamnya. Agar lebih mudah, cermat dibuat berdasarkan pengalaman sehari-hari dan lingkungan siswa. Sehingga siswa lebih percaya diri untuk berkarya membuat cermat.

Cerpen matematika karya guru dan siswa SMP Negeri 1 Dolopo ini kini sudah dibukukan dalam empat buku ber-ISBN. Bisa dijadikan sebagai salah satu model dan bahan kajian dalam pembelajaran matematika, ataupun pada mata pelajaran lain. Selamat mencoba.

\section{DAFTAR PUSTAKA}

Achmad, S. W. (2016). Menulis Kreatif itu Gampang. Yogyakarta: Araska.

Agustiani, R. (2016). The Development Of Mathematics Short Story For Mathematics Learning Topics Adding Fraction With Same Denominator. Jurnal Pendidikan Matematika JPM RAFA, 2(2), 161-180.

Direktorat Pembinaan SMP, T. (2017). Panduan Penilaian oleh Pendidik dan Satuan Pendidikan Sekolah Menengah Pertama. Jakarta: Kementerian Pendidikan dan Kebudayaan.

Gewati, M. (2016). Minat baca Indonesia ada di urutan ke-60 dunia. Kompas.Com, 29. Retrieved from https://edukasi.kompas.com/read/2016/08/29/07175131/minat.baca.indon esia.ada.di.urutan ke-60.dunia

Hakim, A. (2016). Jangan Korupsi, Ayah! Yogyakarta: Lingkarantarnusa.

Hakim, A., \& et al. (2018). The Amazing of love. Badung, Bali: MM (Mudilan Med).

Hakim, A., \& Friends. (2017a). An Antologi Math Story: The Art Of Math. Badung, Bali: MM (Mudilan Med).

Hakim, A., \& Friends. (2017b). Cinta Bertabur Logika. Kebumen: Intishar Publishing.

Hakim, A., \& Friends. (2017c). Cinta di Balik Angka. Kebumen: Intishar Publishing.

Haryanti, T. (2014). Membangun Budaya Literasi Dengan pendekatan Kultural di Komunitas Adat. Retrieved from www.triharyanti.id website: http://www.triniharyanti.id/2014/02/membangun-budaya-literasidengan.html

Jusran, H. R. (2017). Opini; Mengapa Budaya Literasi Penting di Sekolah? Retrieved 
from pijarnews.com (diunduh di Madiun, 10 April 2018) website: https://www.pijarnews.com/opini.-mengapa-budaya-literasi-penting-disekolah/

Kemdikbud, T. (2017). Modul Pelatihan Instruktur Kurikulum 2013: Inspirasi Pembelajaran Dan Penilaian Mata Pelajaran Matematika. Jakarta: Kementerian Pendidikan dan Kebudayaan.

Moma, L. (2013). Kemampuan Berpikir Kreatif Matematika. Makalah. Seminar Nasional Pendidikan Matematika Di Universitas Pattimura. Ambon, 3.

Novitasari, W. D. (2012). Pengembangan media cerpen matematika untuk menyelesaikan soal cerita pada materi kubus dan balok. Surabaya: IAIN Sunan Ampel Surabaya.

Panjaitan, A. H., \& Surya, E. (2018). Creative Thinking (Berpikir Kreatif) Dalam Pembelajaran Matematika. Diakses Di Https://Www.Researchgate.Net/Publication/321849189 (Diunduh 10 April 2018).

Putra, T. T. (2012). Meningkatkan Kemampuan Berpikir Kreatif Siswa dengan Pembelajaran Berbasis Masalah. Jurnal Pendidikan Matematika, 1(1), 22-26.

Rhosalia, L. A., Laksono, K., \& Sukartiningsih, W. (2016). Kemampuan Berpikir Kreatif dalam Menulis Naratif Siswa Kelas V Sekolah Dasar Negeri di Kecamatan Gayungan Surabaya. Jurnal Review Pendidikan Dasar: Jurnal Kajian Pendidikan Dan Hasil Penelitian, 2(2), 166-174.

Rowe, A. J. (2005). Creative Intelligence. Bandung: Penerbit Kaifa.

Siswono, T. Y. E. (2018). Pembelajaran Matematika Berbasis Pengajuan dan Pemecahan Masalah. Bandung: Remaja Rosdakarya.

Wikipedia. (2017). Cerita Pendek. Retrieved from Wikipedia website: https://id.wikipedia.org/wiki/Cerita_pendek 